\title{
ANNUAL MEETING OF SOCIETY OF AMERICAN FORESTERS
}

More than 1,000 foresters from all over the United States and Canada convened for a four-day review of the forest resource situation and the progress being made in growing and utilizing timber at the annual meeting of the Society of American Foresters in Biloxi, Miss., December 12-15.

Among those giving addresses were Peter Watzek, Crossett Industries, Crossett, Ark., who spoke on "Integrating Production and Industry"; William J. McGlothin, director of the Board of Control for Southern Regional Education, Atlanta, Ga., on "Regional Education in Forestry"; C. D. Dosker, Gamble Bros., Louisville, Ky., on "Trends in Hardwood Utilization"; and William Duerr, U.S. Forest Service, Washington, D.C., on "Forest Future of the South."

Forestry educators discussed the place of adult education in the forestry program. Forest managers discussed the role of prescribed fire in southern forest management. Consulting foresters considered the licensing of foresters in the public interest. Water managers considered the role of forests in the management of water. 